\title{
Environmental changes on Yugorski Peninsula, Kara Sea, Russia, during the last 12,800 radiocarbon years
}

\author{
Andrei A. Andreev ${ }^{\mathrm{a}, *}$, William F. Manley ${ }^{\mathrm{b}}$, Ólafur Ingólfsson ${ }^{\mathrm{c}}$, Steve L. Forman ${ }^{\mathrm{d}}$ \\ ${ }^{a}$ Alfred-Wegener-Institut für Polar- und Meeresforschung, Forschungsstelle Potsdam, Telegrafenberg A43, 14473 Potsdam, Germany \\ ${ }^{\mathrm{b}}$ Institute of Arctic and Alpine Research, University of Colorado, Boulder, CO 80309, USA \\ ${ }^{\mathrm{c}}$ Earth Sciences Centre, Göteborg University, Box 460, Göteborg S-40530, Sweden \\ ${ }^{\mathrm{d}}$ Department of Geological Sciences, University of Illinois at Chicago, Chicago, IL 60607, USA
}

Received 6 January 2000; accepted 23 May 2001

\begin{abstract}
New pollen and radiocarbon data from an 8.6-m coastal section, Cape Shpindler $\left(69^{\circ} 43^{\prime} \mathrm{N} ; 62^{\circ} 48^{\prime} \mathrm{E}\right)$, Yugorski Peninsula, document the latest Pleistocene and Holocene environmental history of this low Arctic region. Twelve AMS ${ }^{14} \mathrm{C}$ dates indicate that the deposits accumulated since about 13,000 until 2000 radiocarbon years BP. A thermokarst lake formed ca. 13,000-12,800 years BP, when scarce arctic tundra vegetation dominated the area. By 12,500 years BP, a shallow lake existed at the site, and Arctic tundra with Poaceae, Cyperaceae, Salix, Saxifraga, and Artemisia dominated nearby vegetation. Climate was colder than today. Betula nana became dominant during the Early Preboreal period about 9500 years BP, responding to a warm event, which was one of the warmest during the Holocene. Decline in B. nana and Salix after 9500 years BP reflects a brief event of Preboreal cooling. A subsequent increase in Betula and Alnus fruticosa pollen percentages reflects amelioration of environmental conditions at the end of Preboreal period (ca. 9300 years BP). A decline in arboreal taxa later, with a dramatic increase in herb taxa, reflects a short cold event at about 9200 years BP. The pollen data reflect a northward movement of tree birch, peaking at the middle Boreal period, around 8500 years BP. Open Betula forest existed on the Kara Sea coast of the Yugorski Peninsula during the Atlantic period (8000-4500 years BP), indicating that climate was significantly warmer than today. Deteriorating climate around the Atlantic-Subboreal boundary (ca. 4500 years BP) is recorded by a decline in Betula percentages. Sedimentation slowed at the site, and processes of denudation and/or soil formation started at the beginning of the Subatlantic period, when vegetation cover on Yugorski Peninsula shifted to near-modern assemblages. (C) 2001 Elsevier Science B.V. All rights reserved.
\end{abstract}

Keywords: Late Quaternary paleoenvironment; paleovegetation; palynology; Russian Arctic; Kara Sea coast

\footnotetext{
* Corresponding author.

E-mail addresses: aandreev@awi-potsdam.de (A.A. Andreev), William.Manley@colorado.edu (W.F. Manley), olafur@gvc.gu.se (Ó. Ingólfsson), slf@uic.edu (S.L. Forman).
}

\section{Introduction}

Despite increased research over the last decade, relatively little is known about past climatic and environmental fluctuations across broad areas of the Eurasian Arctic (Velichko et al., 1997; Andreev and Klimanov, 2000). Only a few well-dated paleoenvi- 
ronmental records exist from the northeastern part of the European Arctic (Kara Sea region, Fig. 1). In this area, there are only two sites where vegetation changes have been well documented for the latest Pleistocene and Holocene period: the Khaipudurskaya Guba and Baidaratskaya Guba sites (Fig. 1) (Bolikhovskaya et al., 1988; Velichko et al., 1997; Andreev et al., 1998).

Here we present palynological data and 12 new AMS ages for a stratigraphic section at Cape Shpindler, which lies 140 and $185 \mathrm{~km}$ from the previously documented sites, respectively. The pollen spectra at Cape Shpindler record trends and oscillations in vegetation since about 12,800 years BP (radiocarbon years), and document regional, cli- mate-induced fluctuations in tundra environments and treeline position.

\subsection{Setting}

Cape Shpindler is centrally located on the Kara Sea coast of Yugorski Peninsula, about $40 \mathrm{~km}$ east of the settlement of Amderma (Fig. 1). Coastal and thermokarst erosion has created 15-50-m-high coastal cliffs, trending WNW-ESE, and extending intermittently for about $25 \mathrm{~km}$. During the 1998 summer field season, we described and sampled the stratigraphy of about $25 \mathrm{~km}$ of coastal sections, immediately east and west of the Khuptyakha River. Most of the exposed deposits relate to marine and

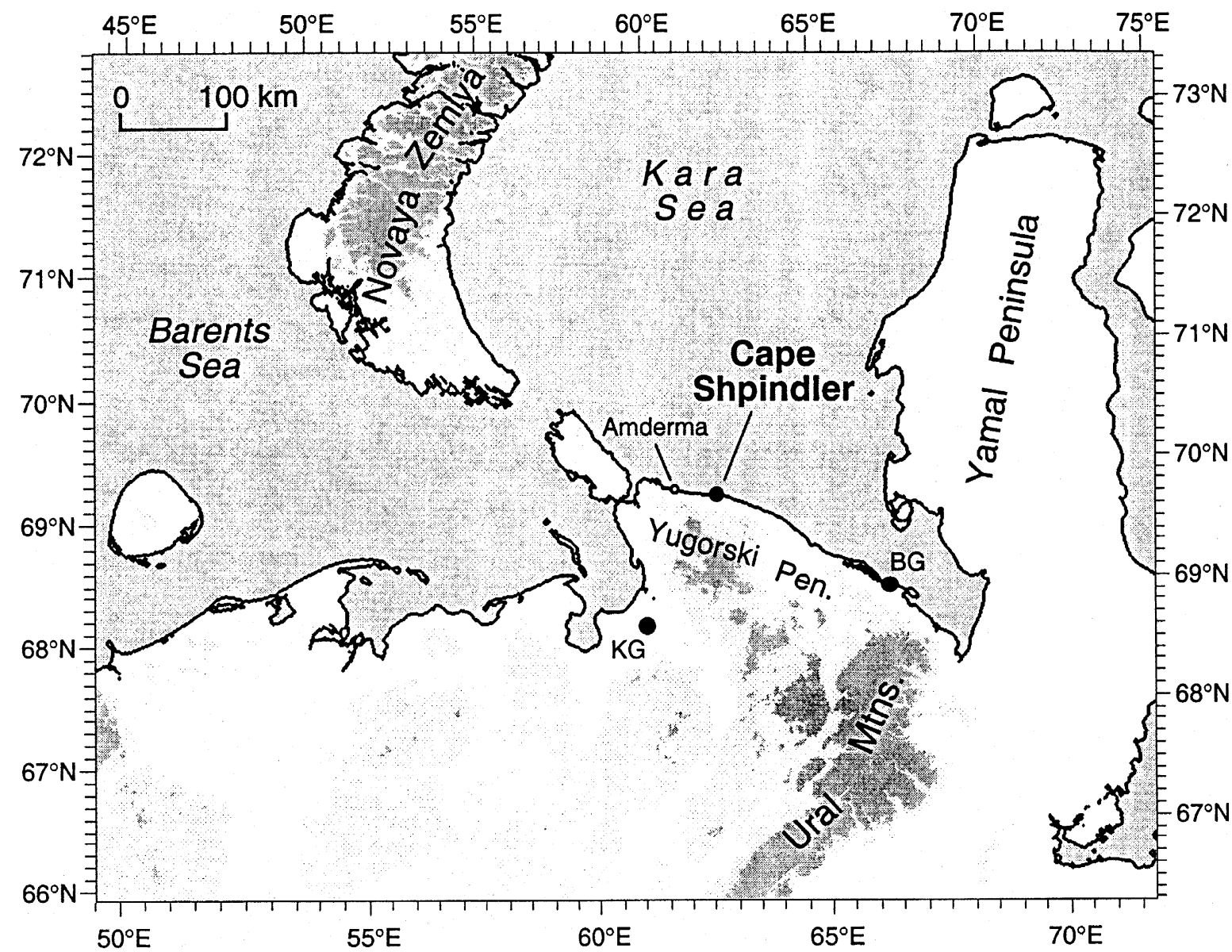

Fig. 1. Map of the southern Kara Sea region, showing the location of Cape Shpindler. Light shading depicts elevations of 100-200 m, and dark gray shading shows elevations $>200 \mathrm{~m}$. The two previously documented pollen sections are: BG, Baidaratskaya Guba, and KG, Khaipudurskaya Guba. 


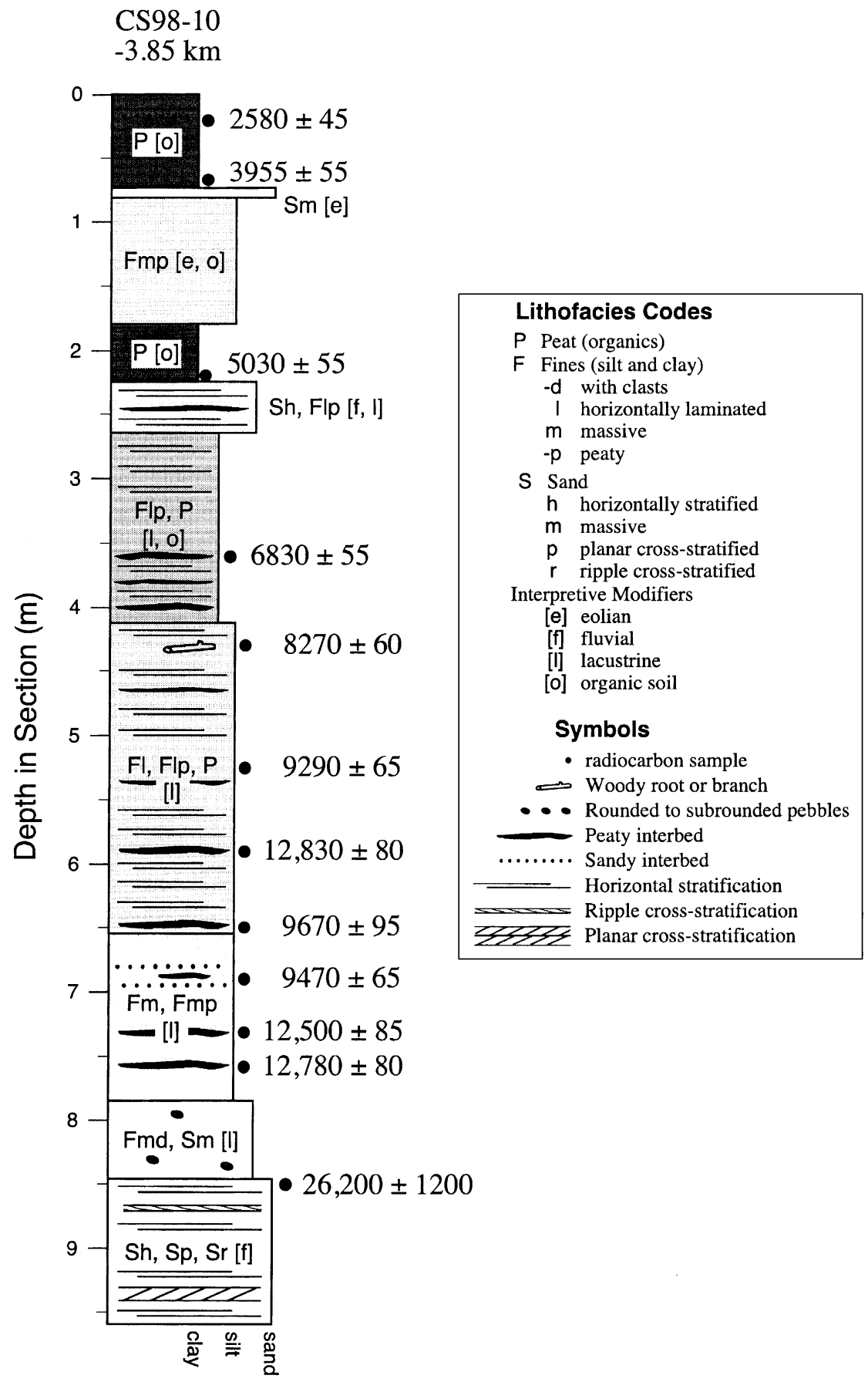

Fig. 2. Stratigraphy of section CS98-10 at $-3.85 \mathrm{~km}$ on the horizontal scale of Manley et al. (2001-this volume), showing sediment lithologies, structures, inferred genesis, and radiocarbon ages. Shading from light to dark gray approximately depicts organic content. 
glacial events before the Late Weichselian (see Manley et al., 2001-this volume). However, at one site-section CS98-10 $\left(69^{\circ} 43^{\prime} \mathrm{N} ; 62^{\circ} 48^{\prime} \mathrm{E}\right.$; about 3.85 $\mathrm{km}$ east of the mouth of the Khuptyakha River) latest Pleistocene and Holocene sediments attain a thickness greater than $11.1 \mathrm{~m}$ (Fig. 2).

The section lies near the center of a ca. 400-mwide thermokarst depression exposed in cross section along the coastal bluffs (see Manley et al., 2001-this volume for cross section in relation to laterally extensive lithostratigraphic units). Peat, organic silt, and-less commonly-fine sand fill the small basin. These deposits are laterally correlative with other Late Glacial and Holocene deposits (Unit F of Manley et al., 2001-this volume), which elsewhere vary from 0 to about $5 \mathrm{~m}$ in thickness. Based on nearby exposures, the thermokarst sequence is probably underlain (below sea level) by Weichselian till and deformed pre-Weichselian marine and fluvial sediments. The upper surface of the thermokarst depression is nearly flat, ellipsoidal, and inset into a hummocky landscape. Permafrost attains a thickness of $>400 \mathrm{~m}$ in this part of the Russian Arctic (Sukhodol'sky, 1988).

\subsection{Climate}

Mean July temperature is about $6-8{ }^{\circ} \mathrm{C}$, mean January temperature is about -20 to $-22{ }^{\circ} \mathrm{C}$, and mean annual temperature is about $-8{ }^{\circ} \mathrm{C}$. The total annual precipitation is about $400-500 \mathrm{~mm}$, with $50 \%$ of the precipitation occurring during the summer (Atlas Arktiki, 1985). Oceanic influences dominate over continental ones.

\subsection{Vegetation}

This area belongs to the zone of subarctic tundra (Aleksandrova, 1980). Moss grass-low shrub tundra dominates the vegetation, with species such as $B e$ tula nana, Salix nummularia, Dryas octapetala, Empetrum hermaphroditum, Vaccinium vitus-idaea, Saxifraga, Oxyria digyna, Alopecurus alpinum, Poa abbreviata, Carex stans, C. rotundifolia, Eriophorum medium, and mosses such as Aulacomnium trigidum, Drepanocladus iniciatus, Calliergon sar- mentosum, and Hylocomium splendens. Soils in the area are tundra-gley and peaty-gley (histosols and inceptisols) with an active-layer thickness ca. 30-40 cm (Atlas Arktiki, 1985).

\section{Field and laboratory methods}

The section (Fig. 2) was described using a vertical stadia rod, hand-held level, and measuring tape. A modified lithofacies code was used to highlight sediment lithologies and sedimentary structures (cf. Eyles et al., 1983). The exposure with numerous lenses of peat inclusions was measured up to $11.1 \mathrm{~m}$ above sea level (asl). The upper $8.6 \mathrm{~m}$ of the section was sampled at $10-\mathrm{cm}$ intervals. Samples were collected by first cleaning with a shovel to expose frozen deposits, then cutting contiguous samples at $10-\mathrm{cm}$ intervals and transferring them to sample bags. Organic-rich horizons were further sampled for radiocarbon dating. Radiocarbon samples were wet sieved, handpicked, rinsed in deionized water, and dried under vacuum. The samples received a standard acid-base-acid and were dated at the NSF Arizona AMS Radiocarbon Facility.

Pollen samples were prepared using slight modifications of standard techniques (Faegri et al., 1989). Modifications involved: multiple treatments of boiling $\mathrm{HF}$, up to $3 \mathrm{~h}$ each, punctuated by rinses with warm, concentrated $\mathrm{HCl} ; 3$ min of acetolysis; and fine sieving of all samples with an $8-\mu \mathrm{m}$ nitex screen (Cwynar, et al., 1979). A mild stain was applied using a $0.01 \%$ solution of safranin.

For each sample, 300-500 terrestrial pollen grains were counted at $\times 400$ magnification, and spores were tallied in addition. Determination of relative frequency of pollen was calculated based upon the tree and herbs pollen sum; the percentage of spores was based upon a sum of pollen and spores; the percentage of redeposited taxa (Tertiary spores and Pinaceae) was based upon a sum of pollen and redeposited taxa; and the percentage of algae was based upon a sum of pollen and algae (Berglund and Ralska-Jasiveczowa, 1986). Pollen concentration was calculated using the method of Stockmarr (1971). The TILIA plotting program was used for graphing the pollen data (Grimm, 1991). 


\section{Results}

\subsection{Lithostratigraphy}

Lower energy fluvial sands comprise the lowermost $1.1 \mathrm{~m}$ of the exposed section (Fig. 2). The next $6.2 \mathrm{~m}$ of section $(8.45-2.25 \mathrm{~m})$ consists of massive to laminated clayey silt to sandy silt with intraclasts, seams, and common, thin beds of peat or organic detritus. The interval appears to represent deposition in a shallowing lake $(8.45-4.1 \mathrm{~m})$, and is capped by tundra-gley and peaty-gley soils $(4.1-2.25 \mathrm{~m})$. Woody macrofossils (twigs) commonly occur over depths of 2.7-6.9 m.

A peaty soil lies between 2.25 and $1.7 \mathrm{~m}$. At the top of the section lies a 1-m-thick bed of loess, a thin bed of eolian or sheetwash sand, and a 70-cm-thick, decomposed tundra soil. Based on lithology and lateral relations, the section appears to record the filling of a thermokarst depression formed as buried, massive ground ice melted during the latest Pleistocene and early Holocene (cf. Astakhov, 1995).

\subsection{Radiocarbon chronology}

Twelve AMS ${ }^{14} \mathrm{C}$ determinations (Table 1, Fig. 2) provide a chronology for paleoenvironmental changes. A date of $9670 \pm 95$ years BP at a depth of $6.50 \mathrm{~m}$ creates a stratigraphic age reversal, but is not statistically different (at \pm 2 S.D.) from a date obtained $40 \mathrm{~cm}$ lower in the section. Two of the other age estimates are suspect. A date of $12,830 \pm 80$ years BP at a depth of $5.90 \mathrm{~m}$ creates a significant age inversion. Plant macrofossils at this level were apparently reworked from lower in the section. The oldest date, 26,200 \pm 1200 years BP, was obtained on a small sample $(<1 \mathrm{mg})$ of plant fragments near the base of the section. Very low pollen concentrations, ancient conifer (Pinaceae) pollen, and Tertiary spores at this level suggest redeposition of older organic materials. No other dates $>13,000$ years BP have been obtained on postglacial deposits elsewhere at Cape Shpindler (Unit F, Manley et al., 2001-this volume). For these reasons, we conclude that the small sample consisted of detrital, redeposited fragments mixed with ca. 13,000 years BP contemporary fragments. The other age estimates range from 12,780 to 2580 years $\mathrm{BP}$, and document accumulation rates of $30-90 \mathrm{~cm} /$ kyear.

\subsection{Pollen stratigraphy}

The following describes the pollen diagram as zoned with the CONISS program (Grimm, 1991) and by visual inspection (Fig. 3). Pollen zone I (PZ-I) on the $860-760-\mathrm{cm}$ depth is notable for large amounts of reworked Tertiary spores and indeterminate Pinaceae. Pollen concentration is extremely low in this zone. Relatively high content of Pediastrum colonies is also noticeable in this zone. PZ-II (760$720 \mathrm{~cm}$ ) includes only one sample. It is notable for large amounts of Poaceae, relatively large amounts

Table 1

AMS radiocarbon ages for section CS98-10 at Cape Shpindler, Yugorski Peninsula, northwest Russia

\begin{tabular}{lclcl}
\hline $\begin{array}{l}\text { Laboratory } \\
\text { number }\end{array}$ & $\begin{array}{l}\text { Radiocarbon age } \\
\left({ }^{14} \text { C year BP }\right)\end{array}$ & Material & Elevation (m asl) & Depth \\
\hline AA-35453 & $2580 \pm 45$ & undetermined plant macrofossils & 10.90 & 0.20 \\
AA-35452 & $3955 \pm 55$ & undetermined plant macrofossils & 10.40 & 0.70 \\
AA-31387 & $5030 \pm 55$ & woody twig & 8.90 & 2.20 \\
AA-35451 & $6830 \pm 55$ & undetermined plant macrofossils & 7.50 & 3.60 \\
AA-35450 & $8270 \pm 60$ & undetermined plant macrofossils & 6.80 & 4.30 \\
AA-35449 & $9290 \pm 65$ & undetermined plant macrofossils & 5.85 & 5.25 \\
AA-35448 & $12.830 \pm 80$ & undetermined plant macrofossils & 5.20 & 5.90 \\
AA-31386 & $9670 \pm 95$ & undetermined plant macrofossils & 4.60 & 6.50 \\
AA-35447 & $9.470 \pm 65$ & undetermined plant macrofossils & 4.20 & 6.90 \\
AA-31385 & $12.500 \pm 85$ & undetermined plant macrofossils & 3.78 & 7.32 \\
AA-35446 & $12.780 \pm 80$ & undetermined plant macrofossils & 3.52 & 7.58 \\
AA-35445 & $26.200 \pm 1200$ & undetermined plant macrofossils & 2.60 & 8.50 \\
\hline
\end{tabular}







of Salix, Artemisia, and Saxifraga pollen. Pollen concentration is low in this zone. PZ-III (720-690 $\mathrm{cm})$ also includes only one sample. It is characterized by a dramatic increase in Betula nana pollen percentages, while Poaceae and Saxifraga pollen percentages are significantly decreased. PZ-IV (690$610 \mathrm{~cm})$ is notable for a significant increase in Cyperaceae pollen and a decrease in $B$. nana and Salix. A moderate increase of Picea and Betula sect. Albae percentages is also noticeable in this zone. $\mathrm{PZ}-\mathrm{V}(610-530 \mathrm{~cm})$ is characterized by the increase of Betula sect. Nanae and Albae pollen percentages. A small peak (up to 7\%) of Alnus fruticosa pollen percentages is also seen in this zone. PZ-VI $(530-500 \mathrm{~cm})$ includes only one sample. It is noticeable for a dramatic increase in Poaceae. Small peaks in Ranunculaceae and other herb taxa are also noticeable. PZ-VII $(500-450 \mathrm{~cm})$ is characterized by a significant increase of Betula sect. Albae pollen percentages. Some increase of Cyperaceae pollen percentages is also noticeable in this zone. Pollen concentration is at a maximum in this zone. PZ-VIII $(450-100 \mathrm{~cm})$ is notable for increased amounts of Ericales, Rubus chamaemorus pollen percentages, and Sphagnum spores. PZ-IX $(100-0 \mathrm{~cm})$ is characterized by a decrease of Betula sect. Albae pollen percentages. Some increases in Ranunculaceae pollen amounts at the bottom of this zone and Sphagnum at the top are also noticeable.

\section{Discussion and conclusions}

The pollen data and radiocarbon dates allow a preliminary reconstruction of the latest Pleistocene and Holocene dynamics of vegetation and climate on the Kara Sea coast of Yugorski Peninsula.

Between 13,000 and $12,800{ }^{14} \mathrm{C}$ years $\mathrm{BP}$, a shallow lake formed at the site. The origin of the lake might be due to relative warming and thermokarst formation during the Bølling-Allerød interstadial events. The bottom sediments (PZ-I) contain large amounts of Tertiary spores, indeterminate reworked Pinaceae pollen, and remains of Pediastrum colonies. Pollen concentration is extremely low in this zone. It may reflect scarce vegetation cover or very low pollen productivity, and also high sedimentation rate. A small increase of pollen concentration about 12,800 years ago marks the ending of a rapid phase of lake formation at the beginning of Allerød. Low percentages of Salix, Betula nana, Poaceae, Cyperaceae, Polygonum viviparum, and Ranunculaceae reflect tundra vegetation. Relatively high percentages of Artemisia and Chenopodiaceae pollen may indicate that xerothytic associations grew on drier places.

A pollen spectrum (PZ-II) radiocarbon dated to 12,500 years BP reflects that arctic tundra associations with Poaceae, Cyperaceae, Salix, and Saxifraga dominated the vegetation around the lake. Higher pollen concentration reflects denser vegetation cover and higher pollen productivity at the middle of Allerød. Climate was still cooler than at present.

Radiocarbon dates and the pollen stratigraphy suggest nondeposition and/or erosion of sediment during the Younger Dryas cold period. The upper part of sediments from the Allerød phase may have similarly been removed. Most likely the lake was desiccated during the Younger Dryas.

An early Preboreal warming about 9500 years BP was marked by a sudden change of the pollen spectrum in PZ-III: pollen of Betula nana became dominant, and pollen of Artemisia and Saxifraga almost disappeared. Dwarf birch communities dominated around the lake. Willows were also increasing their role in the vegetation. Poaceae, which dominated during the latest Pleistocene, significantly decreased their participation. According to the pollen spectrum and a ${ }^{14} \mathrm{C}$ AMS date $(9470 \pm 65$ years BP $)$, the early Preboreal time was probably the warmest time in the area during the Holocene.

This is in a good agreement with studies that identify the early Holocene as the warmest time for what is presently the coastal and island areas in the Russian Arctic (Makeyev and Ponomareva, 1988; Ukraintseva et al., 1991; Ukraintseva, 1992; Makeyev et al., 1992; Andreev et al., 1997; Velichko et al., 1997; Serebryanny et al., 1998). The Arctic Ocean coastline was about 100-300 km farther north during the early Preboreal, in comparison to today, which contributed to a warmer and more continental climate. Later climatic fluctuations were moderated by the stronger influence of the Kara Sea.

A decrease of Betula nana and Salix and an increase of Poaceae and Cyperaceae pollen percentages in PZ-IV may reflect a cooling noticed at many 
sites in the northern Eurasia (Nikiforova, 1980, 1982; Andreev et al., 1997; Velichko et al., 1997; Andreev and Klimanov, 2000) and across the North Atlantic region (Björck et al., 1997) for the end of Preboreal time.

An increase of Betula percentages in the upper sediments of PZ-IV, as well as a small peak of Alnus fruticosa pollen, may reflect that some amelioration of environmental conditions occurred at the end of Preboreal period, about 9400-9300 years ago. A dramatic increase of Poaceae pollen percentages, as well as a small peak of Ranunculaceae pollen and other herb taxa like Saxifraga and Caryophyllaceae in PZ-VI, reflect a return to grass-dominated vegetation. This short cold event occurred about 9300 years ago.

A significant increase of Betula sect. Albae pollen percentages, with some increase of Cyperaceae pollen percentages is notable in PZ-VII. Pollen concentration was at a maximum at this zone. That may reflect a significant warming about 8500 years BP, corresponding with a so-called Boreal thermal optimum noticed at many sites in the Northern Eurasia (Andreev et al., 1997; Velichko et al., 1997; Andreev and Klimanov, 2000). Generally, the Boreal period in the northeastern part of the Russian Plain is characterized by the expansion of spruce and birch forest onto the present forest-tundra and particularly the southern tundra areas (Nikiforova, 1980, 1982). Betula pollen percentages also increased in Pechora lowland pollen records dated to early-middle Boreal time (Veinbergs et al., 1995). Tree birch remains dated to the Boreal period are also known on the west coast of Yamal Peninsula (Forman et al., 1999). It is not clear if tree birches grew near the Yugorski site, as no macrofossil remains were found there, but the significant increase of their pollen content could indicate a northern movement of the treeline and/or increased pollen production south of the arctic tree line during the Boreal period.

Some decrease of Betula sect. Albae pollen percentages, with significant decrease of pollen concentration at the bottom of the PZ-VIII, radiocarbon dated to $8270 \pm 60$ years BP, may reflect a cooling. This event appears to correspond with a cold interval about 8200-8000 years BP noticed at many sites in Northern Eurasia (Velichko et al., 1997; Andreev and Klimanov, 2000).
The overlying sediments of PZ-VIII were deposited during the Atlantic chronozone (8000-4500 years BP) according to the AMS dates. Maximum accumulation rates of organic-rich sediments radiocarbon dated to the Atlantic period are noted in many areas of northern Eurasia, and this period has been considered to constitute the Holocene climatic optimum (Nikiforova, 1980, 1982; Velichko et al., 1997; Andreev and Klimanov, 2000). Birch pollen dominated the pollen spectra, reflecting the vegetation cover during this period.

The treeline was ca. $100-150 \mathrm{~km}$ north of the modern treeline during the Atlantic period according to Nikiforova $(1980,1982)$. Open birch forest existed on the western coast of Baidara Bay near a mouth of the Ngoyuyakha River (Andreev et al., 1998). Tree birch remains, dated to the BorealAtlantic period boundary, are also numerous on the western coast of Yamal Peninsula (Forman et al., 1999). We suggest that the birch forest also existed on the Kara Sea coast of the Yugorski Peninsula at this time as well. Increased pollen percentages of more thermophilic taxa such as Ericales, Rubus chamaemorus, and Sphagnum reflect warmer summers. Climate was significantly warmer than at present.

The appearance of Myriophyllum, Typha latifolia pollen, and green algae colonies (Pediastrum) at 275-230-cm depth in the profile reflects wetter conditions at the site. Probably, it reflects the brief existence of a shallow lake, where these plants could grow. It is interesting to note the presence of $T$. latifolia pollen at the $275-\mathrm{cm}$ depth. The northern limit of this species coincides with $13-17{ }^{\circ} \mathrm{C}$ (Isarin and Bohnke, 1999). It is very unlikely that T. latifolia grew at the site, and its pollen was probably wind transported from a long distance, but we assume that its presence reflects warmer climate. The AMS date of $5030 \pm 55$ years BP from $2.20 \mathrm{~m}$ allows us to date the Typha-containing sediments to about $6000-5500$ years BP, noted as a warmest event during the Holocene in many northern Eurasian sites (Velichko et al., 1997; Andreev and Klimanov, 2000).

A decrease of Betula sect. Albae pollen percentages and a dramatic increase of Poaceae as well as some increase of Ranunculaceae pollen percentages in the uppermost sediments (PZ-IX) reflect cooling in the area. During early Subboreal cooling (about 
4500 years BP), there was a return to tundra environment at many arctic and subarctic sites (Nikiforova, 1980, 1982; Veinbergs et al., 1995; Andreev et al., 1997; Velichko et al., 1997; Andreev et al., 1998; Andreev and Klimanov, 2000). This transition also occurred at the Cape Shpindler about 4500 years BP (unidentified plant macrofossils above the transition zone were radiocarbon dated to $3955 \pm 55$ years BP).

Slight increases in Betula and Picea pollen and Sphagnum spore percentages at the 40-cm depth may reflect some warming during the middle Subboreal period (ca. 3500 years BP). It is not clear when accumulation dramatically stopped at the site and when processes of denudation and/or soil formation started on the top of the site. Most likely it occurred at the beginning of the Subatlantic period, coinciding with similar processes at many arctic sites at that time (Peteet et al., 1998). We also assume that the vegetation cover in the Yugorski Peninsula became similar to the modern at the beginning of the Subatlantic period.

\section{Acknowledgements}

This research was made possible through grants and logistical support from the Swedish Natural Sciences Research Council, the Swedish Polar Research Secretariat, Göteborg University, and the National Science Foundation (OPP-9529350 and OPP9529293). Marina Leibman (Earth Cryosphere Institute, Moscow) helped greatly with logistical preparations, and Lisa Doner (INSTAAR, University of Colorado) ably prepared the pollen samples.

\section{References}

Aleksandrova, V.D., 1980. The Arctic and Antarctic: Their Division into Geobotanical Areas. Cambridge Univ. Press, Cambridge.

Andreev, A.A., Klimanov, V.A., 2000. Quantitative Holocene climatic reconstruction from Arctic Russia. Journal of Paleolimnology 24, 81-91.

Andreev, A.A., Tarasov, P.E., Romanenko, F.A., Sulerzhitsky, L.D., 1997. The Younger Dryas pollen records from Sverdrup Island (Kara Sea). Quaternary International 41/42, 135-139.

Andreev, A.A., Tarasov, P.E., Romanenko, F.A., Sulerzhitsky, L.D., Terekhov, K.I., 1998. Vegetation development on the west coast of Baidaratskaya Guba during the Late Pleistocene and Holocene. Stratigrafiya i geologisheskie korrelatsii 5, 235-247 (in Russian).

Astakhov, V.I., 1995. The mode of degradation of Pleistocene permafrost in West Siberia. Quaternary International 28, 119_ 121.

Atlas Arktiki, 1985. GUGK, Moscow, 300 pp. (in Russian).

Berglund, B.E., Ralska-Jasiveczowa, M., 1986. Pollen analysis and pollen diagrams. In: Berglund, B.E. (Ed.), Handbook of Holocene Palaeoecology and Palaeohydrology. Interscience, New York, pp. 455-484.

Björck, S., Rundgren, M., Ingólfsson, Ó., Funder, S., 1997. The Preboreal oscillation around the Nordic Seas: terrestrial and lacustrine responses. Journal of Quaternary Research 12, 455465.

Bolikhovskaya, N.S., Bolikhovskiy, V.F., Klimanov, V.A., 1988. Climatic and cryogenic factors of peatlands development on northeast of European part of USSR during the Holocene. In: Khotynsky, N.A., Klimanov, V.A. (Eds.), Paleoklimaty golotsena evropeiskoi territorii SSSR. Institute of Geography, Academy of Sciences of USSR, Moscow, pp. 36-44 (in Russian).

Cwynar, L.C., Burden, E., McAndrews, J.H., 1979. An inexpensive sieving method for concentrating pollen and spores from fine-grained sediments. Canadian Journal of Earth Sciences 16 (5), 1115-1120.

Eyles, N., Eyles, C.H., Miall, A.D., 1983. Lithofacies types and vertical profile models; an alternative approach to the description and environmental interpretation of glacial diamict and diamictite sequences. Sedimentology 30, 393-410.

Føgri, K., Kaland, P.E., Krzywinski, K., 1989. Textbook of Pollen Analysis, edn. IV. Wiley, New York.

Forman, S.L., Ingólfsson, O., Gataullin, V., Manley, W.F., Lokrantz, H., 1999. Late Quaternary stratigraphy of western Yamal Peninsula, Russia: new constrains on the configuration of the Eurasian ice sheet. Geology 27, 807-810.

Grimm, E., 1991. TILIA and TILIAGRAPH. Illinois State Museum, Springfield, Illinois.

Isarin, R.F.R., Bohnke, S.J.P., 1999. Mean July temperatures during the Younger Dryas in Northern and Central Europe as inferred from climate indicator plan species. Quaternary Research 51, 158-173.

Makeyev, V.M., Ponomareva, D.P., 1988. The Holocene paleogeography of Kotel'nyy Island. In: Gogichaishvili, N. (Ed.), International Conference on the Problems of the Holocene. Metsniereba, Tbilisi, pp. 64-65, Abstracts.

Makeyev, V.M., Bol'shiyanov, D.Yu., Malakhovsky, D.B., 1992 Stratigraphy and geochronology of Severnaya Zemlya Pleistocene deposit. In: Punning, Ya.-M.K., Ivanova, I.K., Kind, N.V., Chichagova, O.A. (Eds.), Geokhronologiya chetvertichnogo perioda. Nauka, Moscow, pp. 32-137 (in Russian).

Manley, W.F., Lokrantz, H., Gataullin, V., Ingólfsson, O., Andersson, T., 2001. Late Quaternary stratigraphy, radiocarbon chronology, and glacial history at Cape Shpindler, southern Kara Sea, Arctic Russia. Global and Planetary Change 31, 239-254 (this volume).

Nikiforova, L.D., 1980. Some questions of environment changes and peat accumulation on the north of Russian Plain. In: Elina, 
G.N. (Ed.), Bolota Evropeiskogo severa SSSR. Institut of Biology, Academy of Sciences of USSR, Karelian Branch, Petrozavodsk, pp. 155-177 (in Russian).

Nikiforova, L.D., 1982. Holocene dynamics of landscape zones in northeast of European part of USSR. In: Velichko, A.A. (Ed.), Razvitie prirody territorii SSSR $\mathrm{v}$ pozdnem pleistotsene $\mathrm{i}$ golotsene. Nauka, Moscow, pp. 154-162 (in Russian).

Peteet, D., Andreev, A., Bardeen, W., Mistretta, F., 1998. Longterm Arctic peatland dynamics, vegetation and climate history of the Pur-Taz region, Western Siberia. Boreas 27, 115-126.

Serebryanny, L., Andreev, A., Malyasova, E., Tarasov, P., Romanenko, F., 1998. Late Glacial and Early Holocene environment in the Russian Arctic. Holocene 8, 323-330.

Stockmarr, J., 1971. Tablets with spores used in absolute pollen analysis. Pollen et Spores 13, 615-621.

Sukhodol'sky, N.I., 1988. Thickness and vertical structure of permafrost. In: Ershov, E.D. (Ed.), Geokriologia SSSR. Evropeiskaya chast' SSSR. Nedra, Moscow, pp. 240-249 (in Russian).
Ukraintseva, V.V., 1992. New paleobotanical and palynological evidences of early Holocene climate warm in high-latitude Arctic. Botanicheskii Zhurnal 75 (1), 70-73 (in Russian).

Ukraintseva, V.V., Arslanov, Kh.A., Belorusova, Zh.M., Ustinov, B.N., 1991. First data about early Holocene flora and vegetation from Bol'shoi Lyakhovskiy Island (New Siberia archipelago). Botanicheskii Zhurnal 74 (6), 70-73 (in Russian).

Veinbergs, I.G., Stelle, V.Ya., Savvaitov, A.I., Yakubovska, I.Ya., 1995. Late Quaternary history of Pechora Sea coast. In: Svitoch, A.A. (Ed.), Korrelazii paleogeographicheskikh sobytiy: materik-shelf-okean. Materialy konferenztsii, Moskva, MGU, 26-28 maya 1992. Publishing House of Moscow University, pp. 106-112 (in Russian).

Velichko, A.A., Andreev, A.A., Klimanov, V.A., 1997. The dynamics of climate and vegetation in the tundra and forest zone during the Late Glacial and Holocene. Quaternary International 41/42, 71-96. 